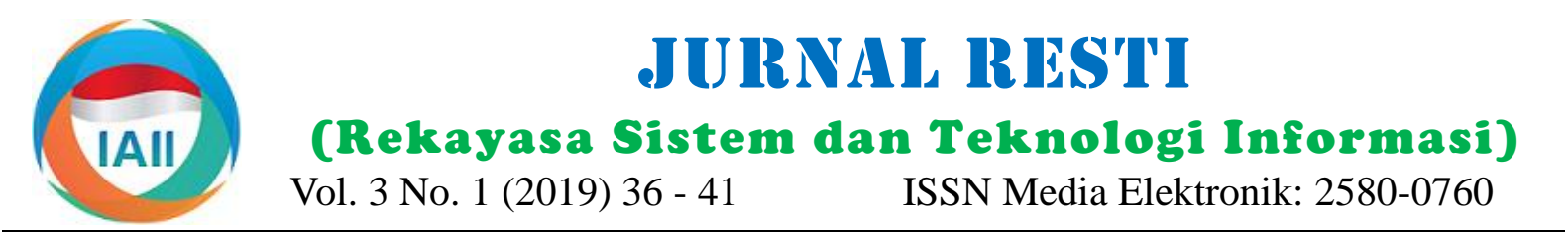

\title{
Analisis Perbandingan Perbaikan Kualitas Citra Pada Motif Batik Dengan Konsep Deteksi Tepi Robert, Sobel, Canny Menggunakan Metode Morfologi
}

\author{
M. Abrar Masril ${ }^{1}$, Yuhandri ${ }^{2}$, Jufriadif Na'am ${ }^{3}$ \\ 1,2,3 Jurusan Teknik Informatika, Universitas Putra Indonesia "YPTK" Padang \\ 19abrar.skom@gmail.com, ${ }^{2}$ yuhandri.yunus@gmail.com, ${ }^{3}$ jufriadif@yahoo.com
}

\begin{abstract}
Image results from quality edge detection are not optimal. From these problems a method is needed to improve the image quality of edge detection. The method used is Dilation Morphology on the results of edge detection of batik patterns. The results of testing the improved image quality of edge detection 10 batik patterns using Dilation Morphology show that Canny operators are able to produce very high accuracy from operators Robert and Sobel, with the percentage of Canny operators is $80 \%$. While Robert operators with a percentage of $40 \%$ and Sobel operators $60 \%$. The application of Dilation Morphology to operators Robert, Sobel and Canny can improve image quality of edge detection and improve accuracy in batik patterns.
\end{abstract}

Keywords: Robert Operator, Sobel Operator, Canny Operator, Edge Detection, Dilation Morphology

\begin{abstract}
Abstrak
Citra hasil dari deteksi tepi kualitas belum optimal. Dari permasalahan tersebut diperlukan sebuah metode untuk meningkatkan kualitas citra deteksi tepi. Metode yang digunakan adalah Morfologi Dilasi pada hasil deteksi tepi pola batik. Hasil dari pengujian perbaikan kualitas citra deteksi tepi 10 pola batik menggunakan Morfologi Dilasi menunjukan bahwa operator Canny mampu menghasilkan akurasi sangat tinggi dari operator Robert dan Sobel, dengan persentase operator Canny adalah $80 \%$. Sedangkan operator Robert dengan persentase $40 \%$ dan operator Sobel 60\%. Penerapan Morfologi Dilasi pada operator Robert, Sobel, dan Canny dapat meningkatkan kualitas citra deteksi tepi dan meningkatkan akurasi pada pola batik.
\end{abstract}

Kata kunci: Operator Robert, Operator Sobel, Operator Canny, Deteksi Tepi, Morfologi Dilasi

\section{Pendahuluan}

Perkembangan teknologi dibidang informatika begitu cepat. Salah satu cabang ilmunya adalah pengolahan citra. Pengolahan citra adalah cabang ilmu informatika untuk memperbaiki kualitas citra agar kualitasnya lebih baik atau lebih mudah diinterpretasi oleh manusia maupun komputer. Salah satu manfaat dari pengolahan citra ini adalah pengenalan pola suatu objek. Pengenalan pola banyak digunakan oleh para peneliti. Ada beberapa penerapan pengenalan pola diantaranya untuk pengenalan wajah, fingerprint, nomor kendaraan dan lain lain.

Proses untuk mendeteksi batas tepi pada citra menggunakan beberapa metode antara lain operator Robert, operator Sobel, operator Prewiit, dan operator
Canny. Citra hasil dari proses deteksi tepi tersebut kualitas masih kurang optimal. Dari permasalahan tersebut diperlukan sebuah metode yang mampu memperbaiki kualitas citra deteksi tepi agar mendapatkan hasil yang lebih baik. Beberapa penelitian yang berhubungan dengan perbaikan kualitas citra menggunakan Morfologi Dilasi antara lain:

Heryawan (2017) operasi Morfologi mampu meningkatkan akurasi citra fundus mata dari DIARETDB1 dan e-optha [1]. Ding, dkk (2016) kolaborasi operasi Dilasi dan template matching pada light field images menghasilkan kualitas gambar yang tinggi [2]. Pal, dkk (2017) teknik kombinasi beberapa operasi Morfologi dan deteksi tepi operator Canny pada gambar fundus retina mata. Setelah metode di uji

Diterima Redaksi : 18-03-2019| Selesai Revisi : 30-03-2019 | Diterbitkan Online : 30-04-2019 
mendapatkan rata-rata akurasi $94,90 \%$ dan rasio Program Grayscale

83,13\% [3]. Said, dkk (2016) operasi Morfologi Input: Img

merupakan salah satu metode yang mampu output: Img

meningkatkan citra sebuah gambar. Hasil uji coba menggunakan matlab terbukti bahwa operasi Morfologi dapat meningkatkan citra gambar ROI [4]. Rahman, dkk (2017) Morfologi Dilasi yang diterapkan pada radar indikator rencana (PPI) dapat meningkatkan kualitas citra radar sehingga dapar meningkatkan kualitas ekstraksi objek [5].

\section{Metode Penelitian}

\subsection{Kerangka kerja penelitian}

Kerangka kerja ini merupakan langkah-langkah yang akan dilakukan dalam rangka penyelesaian masalah yang akan dibahas. Adapun kerangka kerja penelitian ini dapat digambarkan pada Gambar 1.

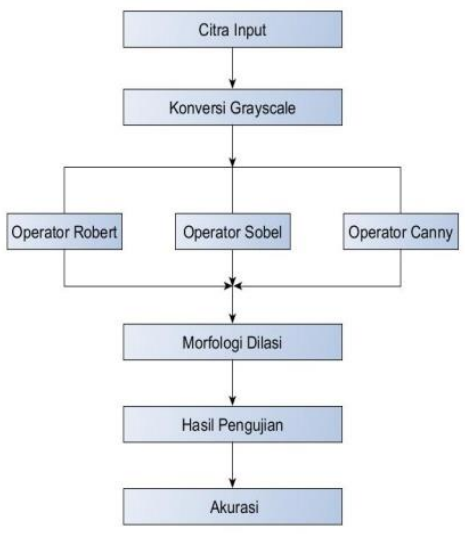

Gambar 1. Kerangka Kerja Penelitian

\subsection{Citra input}

Pada tahap ini citra motif batik akan diinputkan ke dalam program MATLAB versi R2015B.

\subsection{Konversi Grayscale}

Ada berbagai jenis gambar yang terdapat citra digital, seperti citra bewarna, citra abu-abu, dan citra biner. Salah satu cara untuk menunjukkan citra bewarna adalah menggunakan model RGB. Dalam model RGB setiap piksel ditampilkan berupa nilai Merah, Hijau, dan Biru. Ketika mengkonversi nilai RGB ke citra abuabu nilai intensitas dari RGB adalah 0-255[6]. Proses mengkonversi citra motif batik menjadi grayscale menggunakan rumus 1 :

$$
x=0.289 R+0.587 G+0.114 B
$$

Berikut langkah-langkah proses grayscale dapat dilihat pada algoritma seperti dibawah ini:

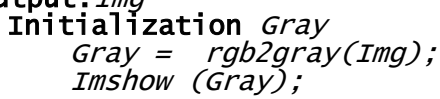

\subsection{Operator Robert}

Operator Robert ini merupakan operator yang menggunakan dua buah kernel $2 \times 2$ yaitu (Gx dan Gy) serta menghitung magnitudo gradien [7]. Implementasi operator Robert seperti pada Gambar 2.

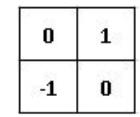

$\mathrm{Gx}$

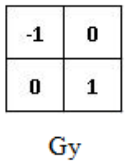

Gy
Gambar 2. Operator Robert Gx dan Gy

Untuk menghitung nilai magnitudo gradien dapat diimplementasikan menggunakan rumus 2 .

$G=\sqrt{G x^{2}+G y^{2}}$

Langkah-langkah proses deteksi tepi Robert dapat dilihat pada algoritma seperti dibawah ini:

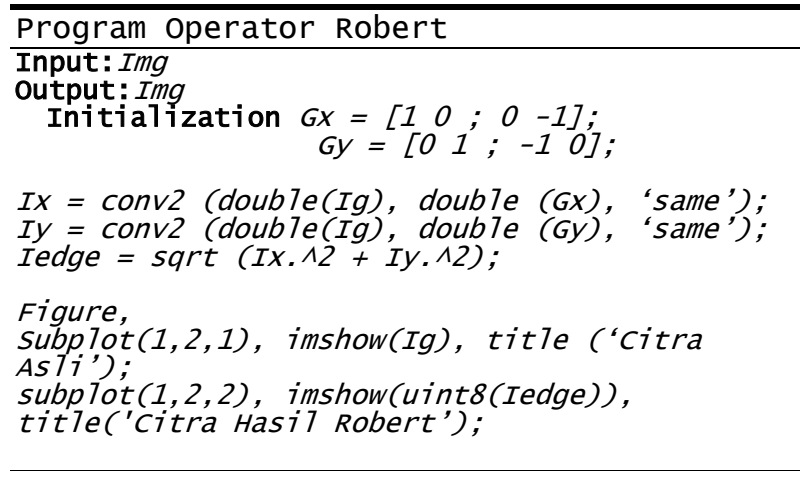

\subsection{Operator Sobel}

Operator Sobel merupakan operator yang biasa digunakan untuk image processing. Operator ini merupakan salah satu metode yang digunakan untuk deteksi tepi suatu objek gambar. Operator Sobel terdiri dari sepasang kernel $3 \times 3$ yaitu kernel Gx dan Gy [8]. Operator Sobel Implementasi operator Robert seperti pada Gambar 3.
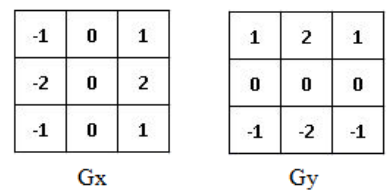

Gambar 3. Operator Sobel Gx dan Gy

Proses kernel operator Sobel dapat didefinisikan dengan mencari nilai tengah kernel seperti Gambar 4. 


$$
\left[\begin{array}{ccc}
A 0 & a 1 & a 2 \\
a 7 & (x, y) & a 3 \\
a 6 & a 5 & a 4
\end{array}\right]
$$

Gambar 4. Penerapan Kernel Operator Sobel

Untuk menghitung nilai magnitudo gradien diimplementasikan menggunakan rumus 3.

$G=\sqrt{G x^{2}+G y^{2}}$

Langkah-langkah proses deteksi tepi Sobel dilihat pada algoritma seperti dibawah ini:

yang searah dengan gradiennya. Dua piksel dengan nilai gradien terkecil akan dihapus sesuai dengan arah $\left(0^{\circ}, 45^{\circ}, 90^{\circ}, 135^{\circ}, 225^{\circ}, 270^{\circ}, 315^{\circ}\right)$.

\section{d. Hyteresis Thresholding}

dapat Piksel dianggap sebagai tepi yang kuat saat piksel memiliki gradient lebih tinggi dari ambang batas. Sedangkan piksel dianggap sebagai tepi lemah jika gradien lemah. Piksel tepi yang kuat langsung menjadi hasil dari deteksi tepi [10].

dapat Berikut langkah-langkah proses canny dapat dilihat pada algoritma seperti dibawah ini:

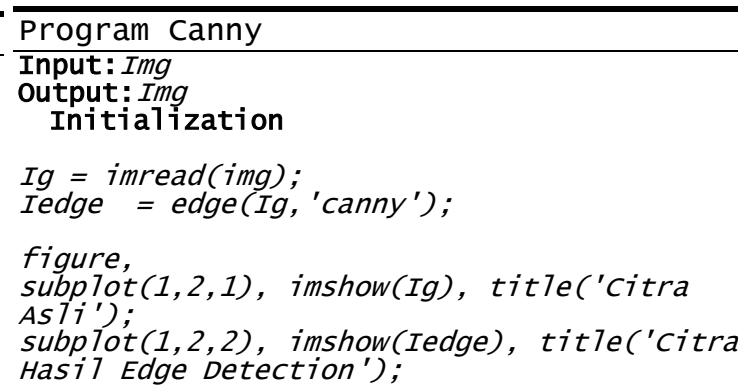

\subsection{Operator Canny}

\subsection{Morfologi}

Morfologi matematis adalah pendekatan berdasarkan Pada tahun 1986 Jhon F. Canny memperkenalkan bentuk topologi dan geometrik untuk melakukan operator Canny untuk mendeteksi tepi suatu objek. Operator Canny berfungsi untuk menghapus noise pada suatu gambar dan menerapkannya pada fungsi Gausian Filter dengan double thresholding [9]. Berikut adalah langkah-langkah operator Canny sebagai berikut:

\section{a. Gaussian Filtering}

Detektor tepi harus kuat terhadap noise. Untuk meminimalkan kemungkinan deteksi tepi salah, noise harus dikurangi. Gaussian filtering dilakukan untuk menghilangkan informasi dan noise yang tidak diinginkan dari gambar. Fungsi Gaussian adalah $\mathrm{G}(x, y)$ dapat diformulasikan dengan rumus 4 .

$$
G(x, y)=\frac{1}{2 \pi \sigma^{2}} \exp \left[\frac{x^{2}+y^{2}}{2 \sigma^{2}}\right]
$$

b. Gradien Calculation

Setelah proses Gaussian filtering selesai, kekuatan tepi ditentukan dengan mencari gradien gambar. Untuk mencari gradien menggunakan operator Sobel. Kemudian menentukan arah tepi menggunakan rumus 2.7. Morfologi Dilasi

5 .

$\theta=\tan ^{-1} \frac{\mathrm{Gy}}{\mathrm{Gx}}$

\section{c. Non Maximal Suppression}

analisis pada gambar dan telah menjadi alat yang sangat berguna untuk mengekstrak struktur dan bentuk geometri dalam banyak aplikasi. Operasi morfologi adalah operasi umum yang diterapkan gambar biner (hitam dan putih) untuk mengubah struktur bentuk objek yang terkandung dalam gambar. Selain diterapkan pada citra biner, sebenarnya, operasi morfologis juga dapat digunakan pada citra grayscale. Dua operasi dasar dalam proses morfologi matematis adalah dilasi dan erosi [11]. Structuring element sering disebut juga sebagai topeng pada image processing. Strel memiliki sebuah titik poros (juga dikenal sebagai titik asal). Titik asal ditandai dengan titik hitam. Strel memiliki dua buah komponen kunci yaitu bentuk dan ukuran, keduanya sangat mempengaruhi proses operasi Morfologi [12]. Bentuk dari structuring element seperti pada Gambar 5.

$$
\begin{array}{|l|l|}
\hline 1 & 1 \\
\hline 1 & 1 \\
\hline
\end{array}
$$

Gambar 5. Element Disk Structure $2 \times 2$

Dilasi adalah proses pelebaran atau pertumbuhan area (5) suatu objek. Area atau objek yang dimaksud adalah area yang meiliki intensitas tinggi pada citra abu-abu [13]. Untuk mengimplementasikan algoritma dilasi dapat menggunakan rumus 6 .

$A \oplus B=\left\{z \mid(B)_{Z} \cap A \neq 0\right\}$ 
Proses pelebaran gambar A oleh structuring element B dapat dilihat pada Gambar 6.

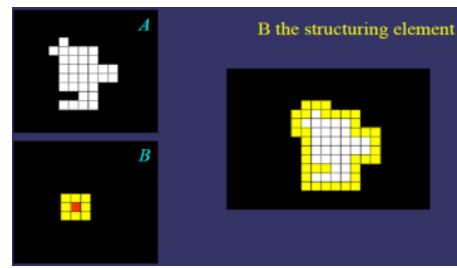

Gambar 6. Penerapan Operasi Dilasi

Langkah-langkah proses Dilasi dapat dilihat pada algoritma seperti dibawah ini:

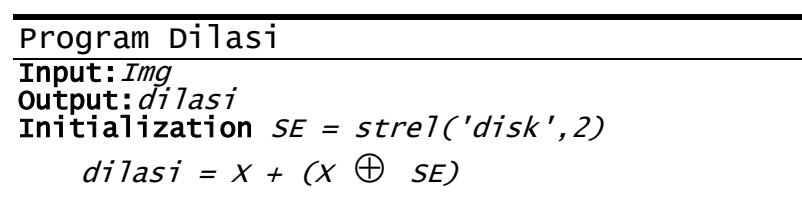

\subsection{Akurasi}

Pada tahap ini hasil dari perbaikan kualitas citra deteksi tepi motif batik akan dilakukan perbandingan tingkat akurasi masing-masing dari setiap operator yang telah diperbaiki kualitas citra deteksi tepi. Selanjutnya proses menghitung tingkat akurasi. Implementasi menghitung tingkat akurasi dapat dilihat pada rumus 7 .

akurasi $=\frac{\text { jumlah hasil data yang terdeteksi }}{\text { jumlah data }} \times 100 \%$

\section{Hasil dan Pembahasan}

Penelitian ini menggunakan sampel sebanyak 10 citra batik. Berikut adalah contoh data citra yang akan diuji seperti pada Tabel 1 .

Tabel 1. Data Sampel Citra Batik

\begin{tabular}{|c|c|c|c|}
\hline No & Gambar Batik & Resolusi & Ukuran \\
\hline 1 & & $1754 \times 1169$ & $1.32 \mathrm{MB}$ \\
\hline 2 & & $1754 \times 1169$ & $1.23 \mathrm{MB}$ \\
\hline
\end{tabular}

Proses perbaikan kualitas citra deteksi tepi motif batik yang dihasilkan oleh operator Robert, Sobel, dan Canny menggunakan program MATLAB versi R2015B dengan tahapan sebagai berikut:

\section{a. Konversi Grayscale}

Proses konversi ini bertujuan mengubah citra RGB motif batik menjadi citra grayscale. Hasil dari konversi grayscale seperti pada Tabel 2.
Tabel 2. Hasil Grayscale

\begin{tabular}{|c|c|c|c|}
\hline No & Citra Awal & $\begin{array}{l}\text { Citra Hasil } \\
\text { Grayscale }\end{array}$ & Histogram \\
\hline 1 & & & \\
\hline 2 & & & \\
\hline
\end{tabular}

b. Deteksi Tepi Operator Robert

Pengujian menggunakan operator Robert bertujuan untuk mendeteksi tepi motif dari batik. Berikut adalah hasil dari deteksi tepi operator Robert seperti pada Tabel 3.

Tabel 3. Hasil Proses Deteksi Tepi Robert

\begin{tabular}{llcl}
\hline No & Citra Grayscale & $\begin{array}{c}\text { Citra Hasil } \\
\text { Deteksi Tepi } \\
\text { Robert }\end{array}$ & Histogram \\
\hline 1 & & & \\
& & & \\
& & & \\
& & & \\
\hline
\end{tabular}

\section{c. Deteksi Tepi Operator Sobel}

(7) Tahap Pengujian ke 2 menggunakan operator Sobel bertujuan untuk mendeteksi tepi motif dari batik. Berikut adalah hasil dari deteksi tepi operator Sobel seperti pada Tabel 4.

Tabel 4. Hasil Proses Deteksi Tepi Sobel

\begin{tabular}{|c|c|c|c|}
\hline No & Citra Grayscale & $\begin{array}{c}\text { Citra Hasil } \\
\text { Deteksi Tepi } \\
\text { Sobel }\end{array}$ & Histogram \\
\hline 1 & 6 & & \\
\hline 2 & 5 & & \\
\hline & & & \\
\hline
\end{tabular}

\section{d. Deteksi Tepi Operator Canny}

Tahap Pengujian ke 3 menggunakan operator Canny bertujuan untuk mendeteksi tepi motif dari batik. Berikut adalah hasil dari deteksi tepi operator Canny seperti pada Tabel 5.

\section{e. Morofologi Dilasi}

Tahap Pengujian ke 4 menggunakan Morfologi Dilasi bertujuan perbaikan kualitas citra deteksi tepi batik hasil dari operator Robert, Sobel, dan Canny. Hasil dari 
perbaikan kualitas citra deteksi tepi batik seperti pada Tabel 6.

Tabel 5. Hasil Proses Deteksi Tepi Canny

\begin{tabular}{|c|c|c|c|}
\hline No & Citra Grayscale & $\begin{array}{c}\text { Citra Hasil } \\
\text { Deteksi Tepi } \\
\text { Canny }\end{array}$ & Histogram \\
\hline 1 & & & \\
\hline 2 & & & \\
\hline
\end{tabular}

Tabel 6. Hasil Morfologi Dilasi

\begin{tabular}{|c|c|c|c|c|}
\hline No & $\begin{array}{c}\text { Operator } \\
\text { Tepi }\end{array}$ & Citra Awal & $\begin{array}{c}\text { Citra Hasil } \\
\text { Morfologi } \\
\text { Dilasi }\end{array}$ & Histogram \\
\hline 1. & Robert & & & \\
\hline 2. & Sobel & & & \\
\hline 3. & Canny & & & \\
\hline
\end{tabular}

Pada Tabel 6 diatas menunjukkan hasil perbaikan kualitas citra deteksi tepi motif batik dari operator Robert, Sobel, dan Canny. Hasil histogram menunjukkan peningkatan nilai grafik dari perbaikan kualitas citra.

\section{f. Akurasi}

Untuk menghitung akurasi hasil perbaikan kualitas citra 3. Perbaikan Kualitas Citra Operator Canny deteksi tepi dengan 3 tahap pengujian seperti berikut :

1. Perbaikan Kualitas Citra Operator Robert

Untuk menghitung hasil perbaikan kualitas citra deteksi tepi operator Robert dapat dilihat dari hasil nilai histogram seperti pada Tabel 7.

Tabel 7. Hasil Histogram Operator Robert

\begin{tabular}{cccc}
\hline No & Data & Histogram Awal & $\begin{array}{c}\text { Histogram Sesudah } \\
\text { Perbaikan Kualitas } \\
\text { Citra Deteksi Tepi } \\
\text { Robert }\end{array}$ \\
\hline 1 & batik_1 & $4.553+04$ & $2.456+05$ \\
2 & batik_2 & $3.287+04$ & $1.924+05$ \\
3 & batik_3 & $3.545+04$ & $2.016+05$ \\
4 & batik_4 & $3.825+04$ & $2.492+05$ \\
5 & batik_5 & $3.326+04$ & $1.84+05$ \\
6 & batik_6 & $5.107+04$ & $2.561+05$ \\
7 & batik_7 & $2.052+04$ & $1.287+05$ \\
8 & batik_8 & $3.516+04$ & $2.039+05$ \\
9 & batik_9 & $4.193+04$ & $2.352+05$ \\
10 & batik_10 & $4.487+04$ & $2.144+05$ \\
\hline
\end{tabular}

Dari hasil Tabel 7 dapat disimpulkan bahwa nilai < kurang optimal. Hasil akurasi pengujian Morfologi 2.352 + 05 hasil perbaikan kualitas citra deteksi tepi Dilasi pada operator Canny adalah: kurang optimal. Hasil akurasi pengujian Morfologi Dilasi pada operator Robert adalah: akurasi $=\frac{\text { jumlah hasil data yang terdeteksi }}{\text { jumlah data }} \times 100 \%$ akurasi $=\frac{4}{10} \times 100 \%=40 \%$

2. Perbaikan Kualitas Citra Operator Sobel Untuk menghitung hasil perbaikan kualitas citra deteksi tepi operator Sobel dapat dilihat dari hasil nilai histogram seperti pada Tabel 8 .

Tabel 8. Hasil Histogram Operator Sobel

\begin{tabular}{cccc}
\hline No & Data & Histogram Awal & $\begin{array}{c}\text { Histogram Sesudah } \\
\text { Perbaikan Kualitas } \\
\text { Citra Deteksi Tepi } \\
\text { Sobel }\end{array}$ \\
\hline 1 & batik_1 & $9.261+04$ & $4.145+05$ \\
2 & batik_2 & $6.915+04$ & $3.345+05$ \\
3 & batik_3 & $6.139+04$ & $3.124+05$ \\
4 & batik_4 & $7.595+04$ & $3.903+05$ \\
5 & batik_5 & $7.957+04$ & $3.551+05$ \\
6 & batik_6 & $1+05$ & $4.015+05$ \\
7 & batik_7 & $6.229+04$ & $3.364+05$ \\
8 & batik_8 & $6.786+04$ & $3.407+05$ \\
9 & batik_9 & $7.418+04$ & $3.531+05$ \\
10 & batik_10 & $6.792+04$ & $2.815+05$ \\
\hline
\end{tabular}

Dari hasil Tabel 8 dapat disimpulkan bahwa nilai < $3.407+05$ hasil perbaikan kualitas citra deteksi tepi kurang optimal. Hasil akurasi pengujian Morfologi Dilasi pada operator Sobel adalah:

$$
\begin{aligned}
& \text { akurasi }=\frac{\text { jumlah hasil data yang terdeteksi }}{\text { jumlah data }} \times 100 \% \\
& \text { akurasi }=\frac{6}{10} \times 100 \%=60 \%
\end{aligned}
$$
deteksi tepi operator Canny dapat dilihat dari hasil nilai histogram seperti pada Tabel 9.

Tabel 9. Hasil Histogram Operator Canny

\begin{tabular}{cccc}
\hline No & Data & Histogram Awal & $\begin{array}{c}\text { Histogram Sesudah } \\
\text { Perbaikan Kualitas } \\
\text { Citra Deteksi Tepi } \\
\text { Canny }\end{array}$ \\
\hline 1 & batik_1 & $2.597+05$ & $8.301+05$ \\
2 & batik_2 & $1.835+05$ & $5.954+05$ \\
3 & batik_3 & $2.947+05$ & $9.456+05$ \\
4 & batik_4 & $1.573+05$ & $5.074+05$ \\
5 & batik_5 & $1.805+05$ & $5.905+05$ \\
6 & batik_6 & $1.562+05$ & $5.009+05$ \\
7 & batik_7 & $3.077+05$ & $9.789+05$ \\
8 & batik_8 & $2.148+05$ & $6.93+05$ \\
9 & batik_9 & $1.84+05$ & $5.972+05$ \\
10 & batik_10 & $2.785+05$ & $8.511+05$ \\
\hline
\end{tabular}

Dari hasil Tabel 9 dapat disimpulkan bahwa nilai < akurasi $=\frac{\text { jumlah hasil data yang terdeteksi }}{\text { jumlah data }} \times 100 \%$
Untuk menghitung hasil perbaikan kualitas citra $5.905+05$ hasil perbaikan kualitas citra deteksi tepi 
akurasi $=\frac{8}{10} \times 100 \%=80 \%$

Dari hasil uji perbaikan kualitas citra deteksi tepi motif batik pada operator Robert, Sobel, dan Canny maka dapat dilihat hasil perbandingan tingkat akurasi. Berikut data hasil perbandingan tingkat akurasi seperti pada Tabel 10 .

Tabel 10. Hasil Perbandingan Akurasi

\begin{tabular}{cccc}
\hline Operator & $\begin{array}{c}\text { Jumlah Data } \\
\text { Uji }\end{array}$ & $\begin{array}{c}\text { Jumlah Hasil } \\
\text { Yang Terdeteksi }\end{array}$ & $\begin{array}{c}\text { Akurasi } \\
(\%)\end{array}$ \\
\hline Robert & 10 & 4 & $40 \%$ \\
Sobel & 10 & 6 & $60 \%$ \\
Canny & 10 & 8 & $80 \%$ \\
\hline
\end{tabular}

Berdasarkan Tabel 7 terlihat hasil pengujian 10 citra batik dengan perbandingan setiap operator dimana operator Canny menghasilkan tingkat akurasi yang sangat tinggi dari operator Robert dan operator Sobel.

\section{Kesimpulan}

Berdasarkan pengujian dan analisa yang telah dilakukan, maka dapat disimpulkan beberapa hal.

1. Morfologi Dilasi pada operator Robert, Sobel, dan Canny dapat meningkatkan kualitas citra deteksi tepi dan meningkatkan akurasi pada pola batik.

2. Hasil dari pengujian perbaikan kualitas citra deteksi tepi 10 motif batik menggunakan Morfologi Dilasi menunjukan bahwa operator Canny mampu menghasilkan akurasi sangat tinggi dari operator Robert dan Sobel, dengan persentase operator Canny adalah $80 \%$. Sedangkan operator Robert dengan persentase $40 \%$ dan operator Sobel $60 \%$.

\section{Daftar Rujukan}

[1] Lukman Heryawan. (2016). Deteksi Dini Retinopati dengan Pengolahan Citra Berbasis Morfologi Matematika. IJCCS, Vol. 11, No.2, july 2017, pp. 209-218. doi.org/10.22146/ijccs.24761.

[2] Ding, J.-J., Wang, N.-C., Chuang, S.-C., \& Chang, R. Y. (2016). Morphology-based disparity estimation and rendering algorithm for light field images. 2016 IEEE International Conference on Consumer Electronics-Taiwan (ICCE$T W$ ). doi:10.1109/icce-tw.2016.7521050.
[3] Pal, S., \& Chatterjee, S. (2017). Mathematical morphology aided optic disk segmentation from retinal images. 2017 3rd International Conference on Condition Assessment Techniques in Electrical Systems (CATCON) .doi:10.1109/catcon.2017.8280249

[4] Said, K. A. M., \& Jambek, A. B. (2016). A study on image processing using mathematical morphological. 2016 3rd International Conference on Electronic Design (ICED).doi:10.1109/iced.2016.7804697.

[5] Rahman, A. N., Heriana, O., Putranto, P., Darwis, F., Pristianto, E. J., \& Wijayanto, Y. N. (2017). Morphological dilation for radar image enhancement. 2017 International Conference on Radar, Antenna, Microwave, Electronics, and Telecommunications (ICRAMET). doi:10.1109/icramet.2017.8253147.

[6] John, J. V., Raji, P. G., Radhakrishnan, B., \& Suresh, L. P. (2017). Automatic number plate localization using dynamic thresholding and morphological operations. 2017 International Conference on Circuit, Power and Computing Technologies (ICCPCT).doi:10.1109/iccpct.2017.8074328.

[7] Reddy, G. B., \& Anusudha, K. (2016). Implementation of image edge detection on FPGA using XSG. 2016 International Conference on Circuit, Power and Computing Technologies (ICCPCT).doi:10.1109/iccpct.2016.7530374.

[8] Mohamad, A. S., Hamzah, R., Mokhtar, A. S., \& Sathar, J. (2017). Sickle cell disease verification via sobel edge algorithms for image processing. 2017 International Conference on Engineering Technology and Technopreneurship (ICE2T).doi:10.1109/ice2t.2017.8215994.

[9] Goel, K., Sehrawat, M., \& Agarwal, A. (2017). Finding the optimal threshold values for edge detection of digital images \& comparing among Bacterial Foraging Algorithm, canny and Sobel Edge Detector. 2017 International Conference on Computing, Communication and Automation (ICCCA).doi:10.1109/ccaa.2017.8229955.

[10] Pawar, K. B., \& Nalbalwar, S. L. (2016). Distributed canny edge detection algorithm using morphological filter. 2016 IEEE International Conference on Recent Trends in Electronics, Information \& Communication Technology (RTEICT).doi:10.1109/rteict.2016.7808087.

[11] Yuhandri, Madenda, Wibowo, Karmilasari. (2017). Object Feature Extraction of Songket Image Using Chain Code Algorithm. 2017 Internasional Journal on Advanced Science Engineering Information Technology . doi: 10.18517/ijaseit.7.1.1479.

[12] Na'am J., Harlan J., Nercahyo G.W, Arlis S., Sahari, Mardison, Rani L.N . (2017). Detection of Infiltrate on Infact Chest X-Ra . TELKOMNIKA, Vol.15, No.4, December 2017, pp. 1943 1951. doi: 10.12928/TELKOMNIKA.v15i4.3163.

[13] Na`am J., (2017). Accuracy of Panoramic Dental X-Ray Imaging in Detection of Proximal Caries with Multiple Morpological Gradient (mMG) Method. Joiv Internasional Journal On Informatics Visualization. doi= 10.30630/joiv.1.1.13 